\title{
Assessment of Knowledge and Attitude towards Hepatitis B Infection Among Dental Students in two Teaching Hospitals of Punjab, Pakistan
}

\author{
Maleeha Khurram, Aneela Qaisar, Khurram Jah Zafar, Arsalan Wahid, Faiza Hassan, Mariyah Javed
}

\begin{abstract}
Objective: To evaluate the knowledge and attitude of dental students towards hepatitis B infection. Study Design: A Cross Sectional Study (survey). Settings: University Medical \& Dental College Faisalabad and FMH College of Medicine and Dentistry Lahore. Duration: Two months from February 1 to March 31, 2018. Methodology: A structured questionnaire consisted of total 27 open and closed ended questions were distributed among 200 first year and final year BDS students. The aim of questionnaire was to assess knowledge and attitude towards hepatitis B infection. The questions were divided into three different sections; Section A: Demographic Detail; Section B: Knowledge Questions and Section C: Attitude Questions. Results: Out of 200 distributed questionnaires $191(95.5 \%)$ were collected and analyzed. The most of the participants were females $149(78 \%)$ students and the number of male students was only $42(22 \%)$ with male to female ratio 1:3.5. The age of the participants ranged from 17-25 years (mean age: 21.4 years). Among 191 participants 99 (52\%) students were from first year BDS class and $92(48 \%)$ from final year BDS class. The majority of study participants $(73 \%)$ had adequate knowledge on hepatitis B infection and its mode of transmission. However, results revealed that there are still misinterpretations regarding the attitudes of participants towards hepatitis B infected patients and only $44 \%$ participants have adequate concept regarding this. Conclusion: The results of this study showed that the overall level of knowledge about hepatitis B infection among the first year and final year BDS students is fairly satisfactory. However, there are still misconceptions regarding the attitudes, which reflect the wrong impression of the disease among students. This calls for well-structured health education programs stressing on such misconceptions.

Keywords: Hepatitis B, Attitude, Knowledge, Dental students.
\end{abstract}

Corresponding Author

Submitted for Publication: 20-10-2019

Accepted for Publication: 29-12-2019

DR. MALEEHA KHURRAM, Assistant Professor of Science of Dental Materials, University Medical \& Dental College, Faisalabad-Pakistan.

Contact / Email: +92 345-3456684, drmaleehakhurram@gmail.com

Citation: Khurram M, Qaisar A, Zafar KJ, Wahid A, Hassan F, Javed M. Assessment of Knowledge and Attitude Towards Hepatitis B Infection

Among Dental Students in Two Teaching Hospitals of Punjab, Pakistan. APMC 2020;14(1):78-82.

\section{INTRODUCTION}

Hepatitis B virus (HBV) infection is an increasing world-wide health problem, affecting more than one third of the world's population. ${ }^{1,2}$ In Pakistan the prevalence of HBV is increasing day by day. ${ }^{2}$ According to the figures published by world health organization four million people in Pakistan have already diagnosed with HBV infection. ${ }^{2,3}$

The main routes for the transmission of HBV infection are unprotected sexual intercourse, unscreened blood transfusions, use of contaminated needles, body tattooing and piercings, treatment by acupuncture, patients on dialysis due to kidney failure, from infected mother to the child. 3,4

In medical and dental set-up the major source of transmission is from needle and wire stick injuries and due to direct contact of saliva or blood from infected patients. ${ }^{1,5}$ According to data published by World health organization in Pakistan the major causes of HBV infection are due to inadequate sterilization of instruments, reuse of needles by health professionals and due to unscreened blood transfusions. ${ }^{2}$

The health care workers, working in close proximity to infected patients and their body fluids are at great risk of occupational exposure to HBV infection. ${ }^{6}$ The risk of occupational exposure increases in developing countries where the incidence of HBV is high in general public and health care facilities are poor with an inadequate waste disposal methods. ${ }^{1}$ Worldwide there are about 35 million health care workers and estimated incidence of percutaneous injuries is approximately 66,000 leading to HBV infection per annum. ${ }^{3,7}$

The incidence of hepatitis $B$ virus infection can be reduced by adopting the universal precautions like the use of protective barriers which includes mask and gloves, proper sterilization of used medical instruments, adequate hospital system for waste management and vaccination of health care workers and general public. 1,2,5 Other methods to reduce the incidence of HBV infection is by giving proper education regarding its methods of transmission to the general public, all health care professionals and students. ${ }^{8,9}$

Medical students can play a very important part in preventing the spread of HBV infection by enhancing the disease knowledge among themselves and the patients they treat on daily basis. ${ }^{7}$ However various studies have confirmed that there is a poor knowledge among health professionals regarding the risks of occupational exposure to HBV infection. 1, 6, 10 A study conducted by Lao democratic People's Republic has shown that $86.5 \%$ of medical students had poor knowledge on modes of HBV transmission and risks associated with the disease. A similar study From Cameroon has highlighted poor practice among the participants of the study with only $10 \%$ vaccination rate against HBV and $55.9 \%$ accidental exposure to blood.1,7,11 Therefore, our study had the objective to assess the knowledge and attitude of dental students in two teaching hospitals of Punjab, towards hepatitis B infection. 


\section{METHODOLOGY}

Study Design: Cross Sectional Study (Survey).

Settings: University Medical \& Dental College Faisalabad and Fatima Memorial Hospital College of Medicine and Dentistry Lahore Pakistan.

Duration: Two months February 1 to March 31, 2018.

Sample Technique: Convenient sampling technique.

Sample Size: Study participants consisted of total 200 students out of which 191 participants completed the questionnaire.

Inclusion and Exclusion Criteria: The students who were present at the day of particular study and were willing to participate were included in the study and those who were not willing to participate were excluded from the study.

Methods: The project was approved by the institutional ethical review committee and all students from the first and final year of the BDS course from the academic year 2017-2018 were included in the study on voluntary basis. Instructions were advised and purpose of the study was explained to all the participants prior to attempt the questionnaire.

Questionnaire: After literature search and preliminary discussion with panel of experts a questionnaire was developed consisting of 27 open and closed ended questions aimed at assessing knowledge and attitude of dental students about HBV. Informed consent was taken from the study participants prior to attempt the questionnaire and confidentiality of data was maintained. Data were collected by using a hard copy of questionnaire.

These questions were divided into three different sections; Section A: Demographic Detail; Section B: Knowledge Questions and Section C: Attitude Questions. Section B and C had Likert based options like Agree, Disagree and Undecided. The survey took an average only 10 to 15 minutes to complete. Statistical Analysis: In order to eliminate the intra-observer error, the data collection process was closely supervised by the same observers at their respective institutes who reviewed and completed the data collection questionnaires. The collected data were entered and analyzed using SPSS version 21.0 (SPSS Inc., Chicago, IL, USA). Data were expressed in frequencies and percentages.

\section{RESULTS}

Total 200 questionnaires were distributed. Out of these 191 participants completed the questionnaire with an overall response rate of $95.5 \%$. The majority of the participants were females $149(78 \%)$ students and the number of male students was only $42(22 \%)$ with male to female ratio was found to be 1:3.5. The age of the participants ranged from 17-25 years (mean age: 21.4). Among 191 participants 99 (52\%) students were from first year BDS class and $92(48 \%)$ from final year BDS class. Majority of the students were from urban area $81.6 \%$ and rest participants were from rural area $18.4 \%$ (Table: 1).

Table 1: General characteristics of the study participants

\begin{tabular}{|l|l|c|}
\hline \multicolumn{2}{|c|}{ Variables } & Number of subjects (\%) \\
\hline \multirow{2}{*}{ Gender } & Male & $42(22 \%)$ \\
\cline { 2 - 3 } & Female & $149(78 \%)$ \\
\hline \multirow{3}{*}{ Age } & $17-20$ & $102(53.4 \%)$ \\
\cline { 2 - 3 } & $21-25$ & $89(46.6 \%)$ \\
\hline \multirow{2}{*}{ Year of Study } & 1 st year & $99(52 \%)$ \\
\cline { 2 - 3 } & Final Year & $92(48 \%)$ \\
\hline \multirow{2}{*}{ Residence } & Rural & $35(18.4 \%)$ \\
\cline { 2 - 3 } & Urban & $156(81.6 \%)$ \\
\hline
\end{tabular}

Overall majority of study participants (73\%) had adequate knowledge on hepatitis B infection and its mode of transmission. Among the students from both the colleges the knowledge level regarding hepatitis B infection was better in final year BDS class as compared to first year BDS class (Table 2).

Table 2: Knowledge of hepatitis B among the study population

\begin{tabular}{|c|c|c|c|c|c|c|c|}
\hline \multirow{2}{*}{ Questions } & \multirow{2}{*}{ Class } & \multicolumn{3}{|c|}{ FMH } & \multicolumn{3}{|c|}{ UMDC } \\
\hline & & Agree & Disagree & Undecided & Agree & Disagree & Undecided \\
\hline \multirow{2}{*}{$\begin{array}{l}\text { Carrier of hepatitis } B \text { are at risk of infecting } \\
\text { others }\end{array}$} & 1styear & $47(94 \%)$ & $3(6 \%)$ & - & $44(89.8 \%)$ & $5(10.2)$ & - \\
\hline & Final Year & $37(88 \%)$ & $4(9.5 \%)$ & $1(2.4 \%)$ & $46(92 \%)$ & $4(8 \%)$ & - \\
\hline \multirow{2}{*}{$\begin{array}{l}\text { Can hepatitis B spread through casual contact } \\
\text { such as holding of hands, sharing of toilet and } \\
\text { drinking in the same glass }\end{array}$} & $1^{\text {st }}$ year & $33(66 \%)$ & $16(32 \%)$ & $1(2 \%)$ & $25(51 \%)$ & $24(49 \%)$ & - \\
\hline & Final Year & $14(33 \%)$ & $27(64 \%)$ & $1(2.4 \%)$ & $21(42 \%)$ & $27(54 \%)$ & $2(4 \%)$ \\
\hline \multirow{2}{*}{$\begin{array}{l}\text { Can hepatitis B spread through contact with } \\
\text { open wound }\end{array}$} & 1st year & $45(90 \%)$ & $4(8 \%)$ & $1(2 \%)$ & $38(77.6 \%)$ & $7(14.3 \%)$ & $4(8.2 \%)$ \\
\hline & Final Year & $32(76.2 \%)$ & $8(19 \%)$ & $2(4.8 \%)$ & $44(88 \%)$ & $5(10 \%)$ & $1(2 \%)$ \\
\hline \multirow{2}{*}{$\begin{array}{l}\text { Can hepatitis B have transmitted by blood and } \\
\text { blood products }\end{array}$} & $1^{\text {st }}$ year & $45(90 \%)$ & $4(8 \%)$ & $1(2 \%)$ & $43(87.8 \%)$ & $6(12.2 \%)$ & - \\
\hline & Final Year & $35(83.3 \%)$ & $7(16.7 \%)$ & - & $43(86 \%)$ & $7(14 \%)$ & - \\
\hline \multirow{2}{*}{$\begin{array}{l}\text { Can hepatitis B have transmitted by un- } \\
\text { sterilized syringes, and surgical instruments }\end{array}$} & $1^{\text {st }}$ year & $43(86 \%)$ & $4(8 \%))$ & $3(6 \%))$ & $46(93.9 \%)$ & $2(4.1 \%)$ & - \\
\hline & Final Year & $35(83.3 \%)$ & $7(16.7 \%)$ & - & $47(94 \%)$ & $2(4 \%)$ & - \\
\hline \multirow{2}{*}{ Can hepatitis B have transmitted through saliva } & $1^{\text {st }}$ year & $44(88 \%)$ & $5(10 \%)$ & $1(2 \%)$ & $21(42.9 \%)$ & $20(40.8 \%)$ & $8(16.3 \%)$ \\
\hline & Final Year & $23(54.8 \%)$ & $16(38.1 \%)$ & $3(7.1 \%)$ & $40(80 \%)$ & $7(14 \%)$ & $3(6 \%)$ \\
\hline \multirow{2}{*}{ Is hepatitis B sexually transmitted disease } & 1styear & $26(52 \%)$ & $23(46 \%)$ & $1(2 \%)$ & $23(46.9 \%)$ & $20(40.8 \%)$ & $5(10.2 \%)$ \\
\hline & Final Year & $24(57.1 \%)$ & $16(38.1 \%)$ & $2(4.8 \%)$ & $42(84 \%)$ & $5(10 \%)$ & $3(6 \%)$ \\
\hline
\end{tabular}




\begin{tabular}{|l|c|c|c|c|c|c|c|}
\hline \multirow{2}{*}{ Can hepatitis B virus cause liver cancer } & 1styear & $38(76 \%)$ & $9(18 \%)$ & $3(6 \%)$ & $22(44 \%)$ & $14(28.6 \%)$ & $13(26.5 \%)$ \\
\cline { 2 - 7 } & Final Year & $31(73.8 \%)$ & $9(21.4 \%)$ & $2(4.8 \%)$ & $40(80 \%)$ & $8(16 \%)$ & $2(4 \%)$ \\
\hline \multirow{2}{*}{ Is hepatitis B vaccine available } & 1styear & $36(72 \%)$ & $10(20 \%)$ & $4(8 \%)$ & $31(63 \%)$ & $13(26.5 \%)$ & $5(10.2)$ \\
\cline { 2 - 7 } & Final Year & $34(81 \%)$ & $7(16.7 \%)$ & $1(2.4 \%)$ & $43(86 \%)$ & $7(14 \%)$ & - \\
\hline \multirow{2}{*}{ Does hepatitis B vaccine provide protection } & 1styear & $40(80 \%)$ & $5(10 \%)$ & $5(10 \%)$ & $32(65.3 \%)$ & $8(16.3 \%)$ & $9(18.4 \%)$ \\
\cline { 2 - 7 } & Final Year & $38(90.5 \%)$ & $3(7.1 \%)$ & $1(2.4 \%)$ & $40(80 \%)$ & $6(12 \%)$ & $4(8 \%)$ \\
\hline \multirow{2}{*}{$\begin{array}{l}\text { Do you think hepatitis B virus has laboratory } \\
\text { test }\end{array}$} & styear & $42(84 \%$ & $2(4 \%)$ & $6(12 \%)$ & $39(79.6 \%)$ & $2(4.1 \%)$ & - \\
\cline { 2 - 7 } & Final Year & $39(92.9 \%)$ & $2(4.8 \%$ & - & $49(98 \%)$ & - & $1(2 \%)$ \\
\hline \multirow{2}{*}{$\begin{array}{l}\text { Is hepatitis B curable/preventable } \\
\text { Do you think that hepatitis B has post-exposure } \\
\text { prophylaxis }\end{array}$} & Final Year & $42(84 \%)$ & $5(10 \%)$ & $3(6 \%)$ & $37(75.5 \%)$ & $6(12.2) \%$ & $6(12.2) \%$ \\
\cline { 2 - 7 } & 1styear & $27(54 \%)$ & $5(11.9 \%)$ & $3(7.1 \%)$ & $46(92 \%)$ & $1(2 \%)$ & $3(12 \%)$ \\
\cline { 2 - 7 } & Final Year & $31(73.8 \%)$ & $5(11.9 \%)$ & $6(14.3 \%)$ & $32(64 \%)$ & $13(26 \%)$ & $5(10 \%)$ \\
\hline
\end{tabular}

On the questions regarding the attitude of students towards hepatitis B infected patients, only $44 \%$ total participants have adequate concept regarding this. These misconceptions were also more common among the junior dental students when compared to those in final year students as documented in Table 3.

Table 3: Attitudes to hepatitis B infected patients among the study population

\begin{tabular}{|c|c|c|c|c|c|c|c|}
\hline \multirow{2}{*}{ Questions } & \multirow{2}{*}{ Class } & \multicolumn{3}{|c|}{ FMH } & \multicolumn{3}{|c|}{ UMDC } \\
\hline & & Agree & Disagree & Undecided & Agree & Disagree & Undecided \\
\hline \multirow{2}{*}{$\begin{array}{l}\text { Would you accept hepatitis B patient in the } \\
\text { same class as yours }\end{array}$} & 1st Year & $35(70 \%)$ & $10(20 \%)$ & $5(10 \%)$ & $31(63.3 \%)$ & $12(24.5)$ & $5(10.2 \%)$ \\
\hline & Final Year & $29(69 \%)$ & $11(26.2 \%)$ & $2(4.8 \%)$ & $40(80 \%)$ & $8(16 \%)$ & $2(4 \%)$ \\
\hline \multirow{2}{*}{$\begin{array}{l}\text { You don't mind sharing food with hepatitis } \\
\text { B patient }\end{array}$} & $1^{\text {st }}$ Year & $19(38 \%)$ & $26(52 \%)$ & $4(8 \%)$ & $21(42.9 \%)$ & $27(55.1 \%)$ & $1(2 \%)$ \\
\hline & Final Year & $19(45.2 \%)$ & $20(47.6 \%)$ & $3(7.1 \%)$ & $28(56 \%)$ & $22(44 \%)$ & - \\
\hline \multirow{2}{*}{$\begin{array}{l}\text { Chronic infection with hepatitis B is } \\
\text { shameful }\end{array}$} & $1^{\text {st }}$ Year & $9(18 \%)$ & $40(80 \%)$ & $1(2 \%)$ & $3(6.1 \%)$ & $44(88 \%)$ & $6(12 \%)$ \\
\hline & Final Year & $11(26.2 \%)$ & $30(71.4 \%)$ & $1(2.4 \%)$ & $3(6 \%)$ & $44(88 \%)$ & $3(6 \%)$ \\
\hline \multirow{2}{*}{$\begin{array}{l}\text { Shaking hand/hugging hepatitis patient } \\
\text { makes you uncomfortable }\end{array}$} & $1^{\text {st }}$ Year & $18(36 \%)$ & $28(56 \%)$ & $4(8 \%)$ & $11(22.4 \%)$ & $35(71.4 \%)$ & $3(6.1 \%)$ \\
\hline & Final Year & $9(21.4 \%)$ & $30(71.4 \%)$ & $3(7.1)$ & $14(28 \%)$ & $34(68 \%)$ & $2(4 \%)$ \\
\hline \multirow{2}{*}{$\begin{array}{l}\text { Caring for hepatitis patient makes you } \\
\text { uncomfortable }\end{array}$} & $1^{\text {st }}$ Year & $12(24 \%)$ & $35(70 \%))$ & $2(4 \%))$ & $11(22.4 \%)$ & $34(69.4 \%)$ & $4(8.2 \%)$ \\
\hline & Final Year & $12(28.6 \%)$ & $30(71.4 \%)$ & - & $6(12 \%)$ & $41(82 \%)$ & $3(6 \%)$ \\
\hline \multirow{2}{*}{$\begin{array}{l}\text { Hepatitis infected doctors/dentist/nurses } \\
\text { should be allowed to work }\end{array}$} & $1^{\text {st }}$ Year & $22(44 \%)$ & $24(48 \%)$ & $4(8 \%)$ & $18(36.7 \%)$ & $27(55.1 \%)$ & $4(8.2 \%)$ \\
\hline & Final Year & $20(47.6 \%)$ & $22(52.4 \%)$ & 2. & $21(42 \%)$ & $25(50 \%)$ & $4(8 \%)$ \\
\hline \multirow{2}{*}{$\begin{array}{l}\text { Medical/dental personal should refuse } \\
\text { treatment to hepatitis patient }\end{array}$} & $1^{\text {st }}$ Year & $16(32 \%)$ & $32(64 \%)$ & $2(4 \%)$ & $12(24.5 \%)$ & $35(71.4 \%)$ & $2(4.1 \%)$ \\
\hline & Final Year & $11(26.2 \%)$ & $29(69 \%)$ & $1(2.4 \%)$ & $4(8 \%)$ & $45(90 \%)$ & $1(2 \%)$ \\
\hline \multirow{2}{*}{$\begin{array}{l}\text { All patients should be tested or hepatitis } \\
\text { infection before they receive health care }\end{array}$} & 1st Year & $45(90 \%)$ & $5(10 \%)$ & - & $42(85.7 \%)$ & $6(12 \%)$ & $1(2 \%)$ \\
\hline & Final Year & $30(71.4 \%)$ & $10(23.8 \%)$ & $2(4.8 \%)$ & $45(90 \%)$ & $3(6 \%)$ & $2(4 \%)$ \\
\hline \multirow{2}{*}{$\begin{array}{l}\text { Following infection control guidelines will } \\
\text { protect from being infected with hepatitis } \\
\text { infection at work }\end{array}$} & $1^{\text {st }}$ Year & $46(92 \%)$ & $3(6 \%)$ & $1(2 \%)$ & $42(85.7 \%)$ & $4(8.2 \%)$ & $3(6.1 \%)$ \\
\hline & Final Year & $34(81 \%)$ & $5(11.9 \%)$ & $3(7.1 \%)$ & $48(96 \%)$ & $1(2 \%)$ & $1(2 \%)$ \\
\hline \multirow{2}{*}{$\begin{array}{l}\text { In Pakistan hepatitis vaccination must be } \\
\text { mandatory for all health care workers }\end{array}$} & 1st Year & $45(90 \%)$ & $4(8 \%)$ & - & $42(85.7 \%)$ & $3(6.1 \%)$ & $4(8.2 \%)$ \\
\hline & Final Year & $31(73.8 \%)$ & $4(9.5 \%)$ & $7(16.7 \%)$ & $49(98 \%)$ & $1(2 \%)$ & - \\
\hline
\end{tabular}

\section{DISCUSSION}

Occupational exposure to blood-borne pathogens like HBV infection remains a notable threat to health care workers mainly in third world countries like Pakistan where this infection is highly widespread. ${ }^{12,13}$

In common, health care workers and the general society have been reported to have negative attitudes towards people with HBV infection and usually first year medical and dental students show considerable fear of transmission of disease, obstructive emotions and professional resistance. ${ }^{14,15}$ There are numerous aspects related with negative HBV infection attitudes like; broad based ideology, a low level of knowledge, young age, panic, over-value risk assessment, not knowing anyone with HBV infection and lacking the encounter of caring for patient with HBV infection. ${ }^{8,16}$
In this study, out of 200 questionnaires distributed among the participants 191 (95.5\%) questionnaires were returned and analyzed. The majority of participants were female (78\%) in this study. This female supremacy was also reported by other studies like Ali $A$ et $a^{2}$ and Paul $P$ et $a^{\beta}$ who reported $65.6 \%$ and $56 \%$ females in their respective studies. ${ }^{2,17}$

The age of the participants in our study ranged from $17-25$ years with the mean age of 21.4 years. Mean age of the participants in other studies were as follows: 22.6 years in the study of Ramakrishnan et a/5 and 23.2 years in the study of Ibrahim $\mathrm{N}$ et al. ${ }^{7}$

The findings of this survey are generally satisfactory despite some disappointing facts on basic knowledge for example $58.6 \%$ students from first year BDS class and 38\% from final year BDS class think that HBV infection can spread through casual contact whereas $47 \%$ students were undecided about www.apmcfmu.com 
the question of hepatitis B post exposure prophylaxis availability. This is in contrast to the study conducted by Ghomraoui FA et a ${ }^{6}$ who reported that $76 \%$ students were well aware about the post exposure prophylaxis management of hepatitis B. Studies like Abdela A et al ${ }^{1}$ also reported that $61 \%$ of fist year and $73 \%$ students of final year BDS class were aware about the mode of transmission of hepatitis B infection. ${ }^{1,6}$

According to results of this study it was also not encouraging to find that vast majority of participants have negative attitude towards hepatitis $B$ infected persons for example in a question regarding sharing of food with hepatitis $B$ patients $53 \%$ students from first year and $46 \%$ students from final year BDS class were disagree in response to this question. Whereas in question regarding healthcare workers infected with hepatitis $B$ should be allowed to work or not, $51.5 \%$ students from first year and $51 \%$ students from final year were disagree with this.

On the other hand it was encouraging to find that the vast majority of the participants considered prevention and control remain the main methods to control HBV and in response to the question that in Pakistan hepatitis vaccination must be mandatory for all health care workers $88 \%$ from first year and $87 \%$ from final year agreed. These results are comparable with the results of Ali $\mathrm{A},{ }^{2} \mathrm{Al}-\mathrm{Jabri} \mathrm{AA}$ et $a \mathrm{l}^{8}$ and Paul $\mathrm{P}$ et al. ${ }^{3}$

\section{CONCLUSION}

According to results of this study, the overall level of knowledge about hepatitis B infection among the first year and final year BDS students is fairly satisfactory. The majority of students showed some knowledge regarding HBV transmission, risk behaviors and prevention. However, there are still misconceptions regarding the attitudes, which reflect a false perception of the disease among students and has the potential to considerably affect the quality of patient care and the doctorpatient relationship.

\section{LIMITATIONS}

Limitation of this study was; that it was conducted in only two teaching hospitals of Punjab, Pakistan.

Therefore, a larger sample size study should be done to make a conclusive finding of knowledge and attitude of upcoming dental surgeons towards hepatitis B infection.

\section{SUGGESTIONS / RECOMMENDATIONS}

This calls for well-structured health education programs stressing on such misconceptions. Frequent workshops and seminars should be organized in order to provide up to date knowledge about HBV infection and means of prevention to both healthcare professionals and students.

\section{CONFLICT OF INTEREST / DISCLOSURE}

No conflict of interest declared.

\section{ACKNOWLEDGEMENTS}

I am grateful to all those with whom I had the pleasure to work during this research. I would especially like to thank Dr Sohail Abbas Khan as my teacher and mentor he has taught me more than I could ever give him credit for here. He has shown me by his example what a good doctor and person should be.

\section{REFERENCES}

1. Abdela A, Woldu B, Haile K, Mathewos B, Deressa $T$. Assessment of knowledge, attitudes and practices toward prevention of hepatitis $B$ virus infection among students of medicine and health sciences in North West Ethiopia. BMC research notes. 2016;9:410-18.

2. Ali A, Khan S, Malik SM, Iqbal MH, Aadil M. Comparison of Knowledge and attitudes regarding hepatitis $B$ among healthcare professionals in Pakistan. Cureus. 2017;9(2):221-28.

3. Paul P, Arumugam B. Knowledge and awareness regarding hepatitis $B$ infection among medical and dental students: a comparative cross-sectional study. Int $J$ Res Med Sci. 2017;12(15):2352-6.

4. Al-Hazmi AH. Knowledge, attitudes and practice of dentists concerning the occupational risks of hepatitis $B$ virus in Al Jouf Province, Saudi Arabia. Niger J Clin Pract. 2015;18(2):276-81.

5. Mahesh R, Arthi C, Victor S, Ashokkumar S. Hepatitis B infection awareness among dental graduate students: a cross sectional study. Int Sch Res Notices. 2014;14(2):1-6.

6. Ghomraoui FA, Alfaqeeh FA, Algadheeb AS, Al-alsheikh AS, AlHamoudi WK, Alswat KA. Medical students' awareness of and compliance with the hepatitis $B$ vaccine in a tertiary care academic hospital: an epidemiological study. J Infect Public Heal. 2016; 9(1):60-5

7. Ibrahim N, Idris A. Hepatitis B awareness among medical students and their vaccination status at Syrian private university. Hepat Res Treat. 2014;14:1-7.

8. Al-Jabri AA, Al-Adawi S, Al-Abri JH, Al-Dhahry SH. Awareness of hepatitis $B$ virus among undergraduate medical and non-medical students. Saudi Med J. 2004;25(4):484-7.

9. Ali M, Imtiaz F, Khan MA, Ahmad B, Umer M, Akhtar S, Malhi TN. Hepatitis $B$ virus and undergraduate students: a study on levels of awareness in universities across Karachi. Pak J Pub Heal. 2018;8(1):75-9.

10. Khalil $H$. Willingness of Saudi dental professionals to treat hepatitis B virus infected patients. Nige J Clin Pract. 2015;18(2):247-50.

11. Kumar S, Basak D, Kumar A, Dasar P, Mishra P, Kumar A et al. Occupational hepatitis B exposure: A peek into Indian dental students' knowledge, opinion, and preventive practices. Interdiscip Perspect Infect Dis. 2015;16(2):1253-7.

12. Tadakamadla J, Kumar S, Swapna LA, Reddy S. Occupational hazards and preventive practices among students and faculty at a private dental institution in India. Stomatologija. 2012;14(1):2832.

13. Marusic V, Markovic-Denic L, Djuric O, Protic D, DubljaninRaspopovic E. Knowledge about blood-borne pathogens and the prevalence of needle stick injuries among medical students in Serbia. Slov J Pub Heal. 2017;56(3):179-84.

14. Choudhury P, Mishra S, Kandula S, Chinnannavar SN, Rout $P$, Panigrahi R. Awareness of hepatitis B infection among healthcare students in a private medical college in Odisha. $\mathrm{J}$ Int Soc Prev Com Dent. 2015;5(2):63-7.

15. Darwish MA, Al Khaldi NM. Knowledge about hepatitis B virus infection among medical students in university of Dammam, eastern region of Saudi Arabia. Life Sci J. 2013;10(3):860-7.

16. Alavian SM, Mahboobi N, Mahboobi N, Savadrudbari MM, Azar PS, Daneshvar S. Iranian dental students' knowledge of hepatitis 
B virus infection and its control practices. J Dent Educ. 2011;75(12):1627-34.

17. Attaullah S, Khan S, Ayaz S, Khan SN, Ali I, Hoti N, Siraj S.

Prevalence of $\mathrm{HBV}$ and $\mathrm{HBV}$ vaccination coverage in health care workers of tertiary hospitals of Peshawar, Pakistan. Virol J. 2011;8:275-9.

\section{AUTHORSHIP AND CONTRIBUTION DECLARATION}

$\begin{array}{lll}\text { AUTHORS } & \text { Contribution to The Paper } & \text { Signatures }\end{array}$

\section{Dr. Maleeha Khurram}

Associate Professor, Department of Science of Dental Materials, University Medical \& Dental

Study Conception and Design, Critical Revision

College, Faisalabad Pakistan

\section{Dr. Aneela Qaisar}

Assistant Professor, Department of Science of Dental Materials, Fatima Memorial Hospital, College

Proof Reading \& Acquisition of Data

of Medicine \& Dentistry, Lahore Pakistan

\section{Dr. Khurram Jah Zafar}

Assistant Professor, Department of Oral \&

Maxillofacial Surgery, Dental Section, Faisalabad

Medical University, Faisalabad Pakistan

\section{Dr. Arsalan Wahid}

Associate Professor \& HOD, Department of Oral

Pathology, University Medical \& Dental College,

Faisalabad Pakistan

\section{Dr. Faiza Hassan}

Associate Professor, Department of Oral Pathology,

Foundation College of Dentistry, Islamabad Pakistan

\section{Dr. Mariyah Javed}

Assistant Professor, Department of Oral Pathology,

University Medical \& Dental College, Faisalabad

Pakistan
Data Collection and Reviewing of Manuscript Khuren

Data Collection \& Data Analysis

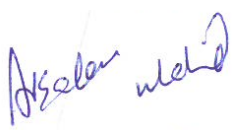

Proof Reading \& Acquisition of Data

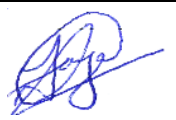

Literature Search and Review

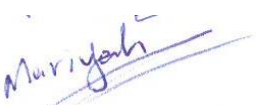

